\title{
Racial Pay Gap: An Analysis of CARL Libraries
}

\section{Yanli Li}

Using data from the 8Rs CARL Libraries Practitioner Survey in 2014, this study assesses the impact of race on the earnings attainment process based on a sample of 392 CARL library practitioners. It determines that there is a significant salary disparity between visible minorities and nonvisible minorities. Racial differences in job characteristics account for a larger portion of the explained racial salary gap than individual and labor market characteristics. The effect of race on salary is shown to be weaker for librarians than for support staff.

\section{Introduction}

Diversity and inclusion are very important in academic libraries because the increasingly diverse patron population will benefit from library staff that can reflect the demographics of their patrons. ${ }^{1}$ Racial equity is vital to recruit and retain a diverse library workforce. The Canadian Association of University Teachers (CAUT) states this in its Position Statement on Equity: "CAUT is committed to securing equity for members of marginalized groups disproportionately excluded from full participation in the academy." ${ }^{2}$ Many studies have discussed various diversifying efforts in hiring and promotion of library staff from ethnic minority groups, such as MLIS enrollment diversification, equity-related workshops, mentorship programs, leadership trainings and financial supports, ${ }^{3}$ whereas pay equity is an understudied measure of racial equity. Although studies show that the racial pay gap exists in the general Canadian labor market, little research has focused on the field of library science.

Canadian Association of Research Libraries (CARL) provides leadership on behalf of Canada's 29 largest university libraries. The 8Rs Redux CARL Libraries' Human Resources Study is a comprehensive study undertaken to investigate the important human resources issues in CARL libraries. It consists of a survey of 26 CARL libraries conducted in 2013 (referred to as the 8Rs Institutional Survey) and a survey of individuals employed in these libraries in 2014 (referred to as the 8Rs Practitioner Survey). ${ }^{4}$ Using the 8Rs Practitioner Survey data, this study will attempt to answer the following questions:

- Is there a significant racial pay gap among CARL library practitioners?

- If a significant racial pay gap exists, what are the key contributing factors?

- How does the effect of race on earnings vary between librarians and support staff?

This paper starts with a review of relevant literature that has explored the racial pay gap in Canadian labor market and in academia and the models of earnings attainment with a focus

\footnotetext{
*Yanli Li is Business and Economics Librarian at Wilfrid Laurier University; email: yli@wlu.ca. (C2021 Yanli Li,
} Attribution-NonCommercial (https://creativecommons.org/licenses/by-nc/4.0/) CC BY-NC. 
on academic libraries. What follows is a presentation of the data, model specifications, and measures. Next is a detailed discussion of the results, followed by the limitations of this study and directions of further research.

\section{Literature Review}

\section{Representation of Visible Minorities in Canadian Libraries}

Members of marginalized groups include visible minorities in Canada. The Employment Equity Act of 1995 defines visible minorities as "persons, other than Aboriginal peoples, who are non-Caucasian in race or non-white in color." 5 The United Nations has requested Canada not to use the term "visible minorities," as the phrase itself is considered discriminatory. ${ }^{6}$ However, given the fact that it is the term used in Canada's human rights legislation and in Statistics Canada data, surveys conducted in the field of Canadian library science still use the term "visible minorities." The first National Survey of Visible Minority Librarians reported that at least 120 librarians identified as visible minorities in $2014 .^{7}$ There was an upward trend in hiring visible minority librarians over a decade. ${ }^{8}$ The 8 Rs Institutional Survey showed that visible minority librarians increased their representation rate from 5 percent in 2003 to 11 percent in $2013 .{ }^{9}$ Nevertheless, visible minorities are underrepresented in the Canadian librarianship (see table 1). According to 2016 Census data, visible minorities comprised only 11 percent of all librarians, ${ }^{10}$ compared to 22 percent of visible minorities in Canada's labor force. ${ }^{11}$ Canadian Association of Professional Academic Librarians (CAPAL) conducted census of academic librarians in 2016 and 2018, which reported 9 percent $^{12}$ and 10 percent $^{13}$ respectively being visible minorities. Not only librarians, other types of library practitioners are also underrepresented. In 2013, 9 percent $(n=54)$ of the other professionals and 8 percent $(n=274)$ of the support staff in CARL libraries belonged to a visible minority group. ${ }^{14}$

\begin{tabular}{|l|c|c|}
\hline \multicolumn{3}{|c|}{ TABLE 1 } \\
Representation of Visible Minorities in Canadian Librarianship \\
\hline Source & Total Number of Librarians & Percent of Visible Minorities \\
\hline 8Rs 2003 Institutional Survey & 826 & $5 \%$ \\
\hline 8Rs 2013 Institutional Survey & 600 & $11 \%$ \\
\hline 2006 Census of Population' ${ }^{15}$ & 11,975 & $10 \%$ \\
\hline 2016 Census of Population & 9,570 & $11 \%$ \\
\hline CAPAL 2016 Census & 866 & $9 \%$ \\
\hline CAPAL 2018 Census & 838 & $10 \%$ \\
\hline
\end{tabular}

\section{Racial Pay Gap in Canada}

To contextualize this research, it is useful to provide an overview of racial pay gap in the Canadian labor market. The 2002 Ethnic Diversity Survey revealed that visible minorities reported lower household incomes, higher poverty rates, and higher chance in experiencing discrimination in comparison to ethnic groups of European origins. ${ }^{16}$ Canadian census data during 1995-2015 also showed that visible minorities have experienced lower average incomes than nonvisible minorities for two decades (see table 2). 


\begin{tabular}{|l|c|c|c|c|c|}
\hline \multicolumn{7}{|c|}{ TABLE 2} \\
Average Total Incomes by Visible Minority Status \\
\hline & $1995^{17}$ & $2000^{18}$ & $2005^{19}$ & $2010^{20}$ & $2015^{21}$ \\
\hline Visible Minorities & 21,958 & 24,385 & 27,750 & 33,322 & 36,955 \\
\hline Nonvisible Minorities & 28,056 & 30,516 & 36,847 & 42,196 & 50,225 \\
\hline
\end{tabular}

The 2016 Census provides data ${ }^{22}$ on average employment income by occupation (see table 3), which can help us understand the state of racial income disparity in library-related occupations. In 2015, visible minorities earned less employment income than nonvisible minorities in 5 out of 7 occupations, including librarians, library assistants and clerks, technicians, archivists, conservators, and curators. Exceptionally, visible minorities earned more as managers or supervisors in libraries and related occupations.

\begin{tabular}{|l|c|c|l|l|l|l|l|}
\hline \multicolumn{7}{|c|}{ Average Employment Income by Occupation and Visible Minority Status in 2015} \\
\hline & Librarians & $\begin{array}{l}\text { Library, } \\
\text { archive, } \\
\text { museum } \\
\text { and art } \\
\text { gallery } \\
\text { managers }\end{array}$ & $\begin{array}{l}\text { Supervisors, } \\
\text { library, } \\
\text { correspondence } \\
\text { and related } \\
\text { information } \\
\text { workers }\end{array}$ & $\begin{array}{l}\text { Library } \\
\text { assistants } \\
\text { and } \\
\text { clerks }\end{array}$ & Archivists & $\begin{array}{l}\text { Conservators } \\
\text { and curators }\end{array}$ & $\begin{array}{l}\text { Library } \\
\text { and public } \\
\text { archive } \\
\text { technicians }\end{array}$ \\
\hline $\begin{array}{l}\text { Visible } \\
\text { Minorities }\end{array}$ & 59,020 & 59,367 & 31,365 & 25,025 & 47,116 & 48,119 & 37,302 \\
\hline $\begin{array}{l}\text { Nonvisible } \\
\text { Minorities }\end{array}$ & 59,221 & 57,242 & 30,716 & 25,530 & 48,050 & 48,651 & 37,455 \\
\hline
\end{tabular}

\section{Racial Pay Gap in Academia}

Very few researchers have explored pay differences by race in Canadian academic libraries. Kandiuk's study revealed that 5.5 percent $(n=57)$ of the visible minority librarians felt disadvantaged and 7.3 percent felt somewhat disadvantaged in salary ${ }^{23}$ Researchers in the United States have undertaken a limited number of studies in this area as well. As opposed to using basic comparisons of group means to examine the racial salary gap in Canada, American studies adopt multiple regression models to assess multiple variables of earnings in the library science labor market. Sweeper and Smith used data from the 2003 National Survey of College Graduates to illustrate the impacts of gender, race, and ethnicity on earnings of library science professionals. No significant difference was identified in earnings among blacks, Asians, Hispanics, and Native Americans as compared to whites. ${ }^{24}$ Two recent studies on racial wage gap focus on the ARL librarians. Galbraith, Kelley, and Groesbeck examined the wage gap between racial minorities and whites based on 35 years of raw salary survey data for ARL librarians. Controlling for institution, years of experience, years of experience squared, position, law or medical library, and sex, their findings showed that the salary gap between racial minorities and whites gradually closed over 1980-2014. ${ }^{25}$ Using a similar methodology, Galbraith, Merrill, and Outzen explored the librarian salary differences between public and private ARL libraries. ARL member libraries in Canada were invited to participate in the survey, but this research did not indicate how many Canadian librarians were included in 
the analysis. The gap between public and private institutions for minority salaries showed to have been insignificant over a period of 34 years. The 2014 adjusted ARL data revealed no significant librarian salary gap between minorities and whites. ${ }^{26}$

Considering faculty members are very similar to academic librarians, as the latter enjoy faculty status in most Canadian academic institutions, it is useful to review the literature on the racial pay gap among faculty members. However, very few Canadian studies have been conducted in this area. CAUT reported that, in 2015, "almost every group of racialized and Aboriginal women and men university teachers earned less than the average for all workers of all sexes, with the exception of Southeast Asian men $(+4.1 \%)$ and Chinese men $(+2.0 \%)$. Non-racialized university professors received $2.9 \%$ above the average for all workers, rising to $+12.3 \%$ for all non-racialized men." ${ }^{27}$ Likewise, being Asian significantly increased faculty salary relative to whites in the United States, ${ }^{28}$ whereas some earlier studies in academia have failed to provide strong evidence that there are remarkable pay differences by race/ethnicity. ${ }^{29}$

\section{The Models of Earnings Attainment}

There are various theories of earnings attainment on which the regression models are built to assess library professionals' salaries. Research in this area provides valuable insights into this present study pertaining to model development and variables selection. Sweeper and Smith categorized the theories of earnings attainment into three schools of thought: (1) the status attainment/human capital perspective; (2) the occupationalist perspective; and (3) the structuralist perspective. Occupationalist/structuralist theories stress the influence of social constraints in individual mobility in the labor market, whereas human capital/status attainment theories emphasize the role of the individuals. ${ }^{30}$ Based on these theories, Sweeper and Smith assessed the impact of three categories of variables on earnings in the library science labor market of the United States: individual variables, job/occupational variables, and labor market variables. Individual variables include sex, age, age squared, race, citizenship, number of children, marital status, and highest degree; job/organizational factors include management position, membership in a professional organization or society, and attendance of professional meetings; labor market factors include sector of employment and geographic region. Two other notable studies on the factors determining librarian salaries, although race is not examined, use variables primarily based on the human capital theory. These studies focus on the role of the characteristics that influences one's work productivity and contribution in the labor market through investment in accumulating knowledge and experience. Van House examined the determinants of ALA librarians' salaries by sex and type of library. ${ }^{31}$ In comparison to Sweeper and Smith, Van House used fewer personal variables but explored more human capital factors including degree, experience as a librarian, tenure in current job, and time taken for personal leaves and for continuing education. The effects of job-related variables on librarian salary were also tested, including level in organization, number of professionals and nonprofessionals supervised, size of organization, activity in professional associations, and number of publications. The research findings showed that academic librarians' salaries largely depended on professional experience for both women and men. Level in organization, tenure on the current job and additional education were significant to male librarians' salary only. Most job-related variables were significant to female librarians only. Personal variables, including family situation and mobility limits, had virtually no effect on

salaries of librarians. Siebert and Young also built their model on the human capital theory to 
test the effects of personal, human capital, and workplace factors on earnings of librarians in Great Britain. ${ }^{32}$ Personal variables included age and children. Human capital factors focused on education and experience, which was specifically measured by years in current institution, years in other institutions, years of nonlibrary work experience, and years of part-time experience. Education index, experience in the current library, and experience in other institutions were all found to be highly significant for librarians. Workplace characteristics were also taken into account such as the size of the town in which the librarian's institution was located and the library size. In addition, other studies on earnings attainment of librarians ${ }^{33}$ and faculty ${ }^{34}$ are worth inclusion and shed light on the present research.

A review of the literature reveals that there are not abundant studies on the earnings attainment in the Canadian library science labor market. Research focusing on the effect of race on pay in Canadian academic libraries is rare. This study will contribute to the original research on this topic.

\section{Data and Methodology}

Salary and race data for Canadian academic library practitioners are not readily available. There are a limited number of data sources, each having its limitation. First, some library associations report summary salary data only but do not collect race information. For instance, CARL has managed an annual library statistics program since 1976 that collects median salary and average salary of librarians. ${ }^{35}$ Since the 1980s, CAUT has administered a biennial Librarian Salary \& Academic Status Survey (LSASS), which reports average librarian salary by sex, age, and region. ${ }^{36}$ However, neither CARL annual statistics nor LSASS survey data includes any race-related information, making it impossible to explore the relationship between salary and race. Second, some associations collect data on salary and race, but there has been a lack of examination of the relationship between the two. CAPAL's censuses of academic librarians in 2016 and 2018 gather race and salary information; however, the summary reports do not present any analysis of the relationship between salary and race, as is the case for the 8 Rs Individual Survey in $2004 .{ }^{37}$ Third, it is very hard to get raw salary and race data on individuals in academic libraries from library associations to make an in-depth examination of salary by race. So far, the 8Rs Practitioner Survey in 2014 is the only available survey that allows for downloading microdata ${ }^{38}$ and therefore forms the basis of this research.

The rich dataset from the 8Rs Practitioner Survey contains valuable demographic and employment information on 837 CARL library staff. Demographic information includes gender, year of birth, aboriginal identity, visible minority status, disability status, and the province where the respondents live. Employment information covers job characteristics, job attitudes, and career development/training/education. Some survey questions are designed for librarians only, such as MLIS (or equivalent) education, additional degrees, what is important in a job, barrier to research, job changes, and retirement. Nonlibrarians are asked separately about their education and perceptions of what is important in a job. To obtain the usable sample data for this research, responses to the survey were filtered out if the participant indicated his or her annual salary as a negative amount, extremely low between zero and $\$ 400$, or extremely high such as $\$ 300,000$ and above. Additionally, the responses were removed if the respondents did not report data for any other variables included in this analysis. In the end, the sample for this study consists of 392 practitioners employed in CARL libraries in 2014. 


\section{Measures}

Following the approach taken by Sweeper and Smith, this study develops multiple regression models to measure salary differences between visible minorities and nonvisible minorities while accounting for a number of different variables. These variables are selected based on the data available in the 8Rs Practitioner Survey and literature review. Table 4 presents all variables included in the models along with their specification and sample mean. The dependent variable is the natural log of salary (Insalary). Salary refers to the annual gross salary (before taxes and deductions) in 2012. The mean of annual salary is $\$ 67,100.41$ and the mean of lnsalary is 11.02. In multiple regression models, this study examines three categories of independent variables and the focal variable captures the visible minority status. The sample mean of each of the dichotomous independent variables in table 4 represents what percentage that respective variable accounts for in the overall sample.

\begin{tabular}{|c|c|c|}
\hline \multicolumn{3}{|c|}{$\begin{array}{c}\text { TABLE } 4 \\
\text { Definition and Full-Sample Means for Variables Used in the Models }\end{array}$} \\
\hline Variable & Specification & $\begin{array}{l}\text { Mean } \\
\text { (Standard Deviation) }\end{array}$ \\
\hline \multicolumn{3}{|l|}{ Dependent Variable } \\
\hline Salary & Annual Gross Salary in 2012 & $\$ 67,100.41(27,127.29)$ \\
\hline In [Salary] & Natural Log of Salary in 2012 & $11.02(0.48)$ \\
\hline \multicolumn{3}{|l|}{ Individual Variables } \\
\hline Visible Minority & Visible Minority $=1$, Otherwise $=0$ & $0.06(0.24)$ \\
\hline Female & Female $=1$, Otherwise $=0$ & $0.78(0.42)$ \\
\hline Disabled & Disabled $=1$, Otherwise $=0$ & $0.06(0.23)$ \\
\hline Age & Age in years as of survey day & $45.6(11.17)$ \\
\hline Age-squared & Age squared & $2,203.96(1,026.84)$ \\
\hline Experience in current library & Years of work in the current library & $12.47(11.18)$ \\
\hline \multicolumn{3}{|l|}{ Highest degree obtained } \\
\hline Without a graduate degree & Without a graduate degree $=1$, Otherwise $=0$ & $0.44(0.50)$ \\
\hline Master's degree & With a master's degree $=1$, Otherwise $=0$ & $0.54(0.50)$ \\
\hline $\mathrm{PhD}$ & With a $\mathrm{PhD}=1$, Otherwise $=0$ & $0.02(0.13)$ \\
\hline \multicolumn{3}{|l|}{ Job Variables } \\
\hline \multicolumn{3}{|l|}{ Staff type } \\
\hline Librarians & Librarians $=1$, Otherwise $=0$ & $0.49(0.50)$ \\
\hline Other professionals & Other professionals $=1$, Otherwise $=0$ & $0.09(0.29)$ \\
\hline Paraprofessional & Paraprofessionals $=1$, Otherwise $=0$ & $0.35(0.48)$ \\
\hline Other support staff & Other support staff $=1$, Otherwise $=0$ & $0.07(0.25)$ \\
\hline \multicolumn{3}{|l|}{ Management Position } \\
\hline Nonmanagement & Nonmanagement $=1$, Otherwise $=0$ & $0.66(0.47)$ \\
\hline Supervisors & Supervisors $=1$, Otherwise $=0$ & $0.15(0.35)$ \\
\hline Middle management & Middle management $=1$, Otherwise $=0$ & $0.12(0.32)$ \\
\hline Senior administrators & Senior administrators $=1$, Otherwise $=0$ & $0.07(0.26)$ \\
\hline
\end{tabular}




\begin{tabular}{|c|c|c|}
\hline \multicolumn{3}{|c|}{$\begin{array}{c}\text { TABLE } 4 \\
\text { Definition and Full-Sample Means for Variables Used in the Models }\end{array}$} \\
\hline Variable & Specification & $\begin{array}{l}\text { Mean } \\
\text { (Standard Deviation) }\end{array}$ \\
\hline \multicolumn{3}{|l|}{ Job category } \\
\hline Public services & Public services $=1$, Otherwise $=0$ & $0.47(0.50)$ \\
\hline Technical services & Technical services $=1$, Otherwise $=0$ & $0.18(0.38)$ \\
\hline Collections & Collections $=1$, Otherwise $=0$ & $0.08(0.27)$ \\
\hline Information technology (IT) & Information technology $=1$, Otherwise $=0$ & $0.06(0.23)$ \\
\hline Management & Management $=1$, Otherwise $=0$ & $0.11(0.31)$ \\
\hline Other category & Other category $=1$, Otherwise $=0$ & $0.10(0.31)$ \\
\hline Permanent & Permanent position $=1$, Otherwise $=0$ & $0.90(0.30)$ \\
\hline Hours & Work hours per week & $36.69(6.21)$ \\
\hline \multicolumn{3}{|l|}{ Labor Market Variable } \\
\hline \multicolumn{3}{|l|}{ Province living in } \\
\hline British Columbia & British Columbia $=1$, Otherwise $=0$ & $0.08(0.27)$ \\
\hline Alberta & Alberta $=1$, Otherwise $=0$ & $0.14(0.34)$ \\
\hline Saskatchewan & Saskatchewan $=1$, Otherwise $=0$ & $0.10(0.30)$ \\
\hline Manitoba & Manitoba $=1$, Otherwise $=0$ & $0.04(0.20)$ \\
\hline Ontario & Ontario $=1$, Otherwise $=0$ & $0.33(0.47)$ \\
\hline Quebec & Quebec $=1$, Otherwise $=0$ & $0.29(0.45)$ \\
\hline Nova Scotia & Nova Scotia $=1$, Otherwise $=0$ & $0.03(0.16)$ \\
\hline
\end{tabular}

The first category of independent variables are individual variables primarily consisting of demographic and human capital factors such as education and experience. This sample is 78 percent female, 6 percent visible minorities and 6 percent with disability. The average age is 45.6 years. Age squared is included in the models to account for the curvilinear relationship between age and salary. The average years of experience in the current library is 12.47 years. The educational attainment measured by the highest degree obtained is recoded into three groups: without a graduate degree, master's degree, and PhD. In Canada, an MLIS (or equivalent) degree is a required qualification for a librarian position. This is reflected in the sample that all librarians have received their MLIS (or equivalent) degree. Overall, 44 percent of all library practitioners do not possess a graduate degree, 54 percent possess a master's degree, and 2 percent obtain a PhD. Specifically, 39 percent of other professionals $(n=36)$ and 7 percent of the paraprofessionals $(n=136)$ have a master's degree. Additionally, 2.6 percent of the librarians $(\mathrm{n}=194)$ and 5.6 percent of other professionals $(\mathrm{n}=36)$ have a $\mathrm{PhD}$ (not shown in table 4).

The second category of independent variables are job variables including staff type, management position, job category, permanent job, and weekly hours. Regarding staff type, nearly half $(49 \%)$ of the sample are librarians, followed by paraprofessionals $(35 \%)$, other professionals (9\%), and other support staff $(7 \%)$. As defined in the 8Rs Practitioner Survey, librarians are professionals who possess a master's degree from a library education program (MLIS or its equivalent) accredited by the American Library Association. Other professionals are those professionals other than librarians "who are not required to have an MLIS degree 
and are not working as a library technician or library assistant and who perform work requiring knowledge of an advanced type." ${ }^{39}$ Other professionals customarily obtain a professional qualification or advanced degree, such as PhD. Meanwhile, support staff are those individuals "who work in a support role and typically do not have a master's degree in library or information science or in another discipline. Support staff includes paraprofessionals who usually possess a technical certificate or diploma from a library technician program (e.g. IT support, library technicians), but they might also work in paraprofessional roles with an undergraduate degree and/or relevant experience (e.g. library assistants)." 40

Management positions in academic libraries include supervisors, middle management, and senior administrators. Examples of middle management are branch head and department head. Senior administrators include head/chief librarian, director, or deputy/assistant head, chief, director. ${ }^{41}$ A large portion (66\%) of the sample do not hold any management position at the library. Among those on management positions, 15 percent are supervisors, 12 percent are middle management, and 7 percent are senior administrators.

The library practitioners are employed in five primary areas: (1) Public Services, including reference, circulation/reserve, instruction, liaison, learning commons, and support activities; (2) Technical Services: including cataloguing/metadata, acquisitions, and support activities; (3) Collections: including acquisitions, management, and preservation of collections in all formats, including special collections; (4) Information Technology (IT): including digital and web services; (5) Management: responsible for budgets and personnel, overseeing operations, instituting policies and accountability measures. ${ }^{42}$ The largest group in the sample is employed in public services (47\%), followed by technical services (18\%), management (11\%), collections (8\%), and IT (6\%). Furthermore, 90 percent of the individuals in the sample work 36.69 hours per week on average.

The third category of variable is labor market variable. Province where the respondent is living is the only labor market variable available in the 8R Practitioner Survey. The sample is not evenly distributed across Canada, with the largest number (33\%) living in Ontario, followed by Quebec (29\%), and the smallest (3\%) in Nova Scotia. This sample excludes individuals living in Prince Edward Island because none of the CARL libraries are located in this province, and those in New Brunswick and Newfoundland and Labrador because data are missing for some variables.

Table 5 shows the percentage distribution of library staff by visible minority status. Nonlibrarians (7.1\%) have a higher rate of visible minorities than librarians (5.7\%). Among nonlibrarians, paraprofessionals $(8.1 \%)$ are more than twice as likely to be visible minorities as other support staff (3.8\%).

\begin{tabular}{|l|c|c|c|c|}
\hline \multicolumn{5}{|c|}{ TABLE 5} \\
Percentage Distribution of Library Staff by Visible Minority Status \\
\hline & $\begin{array}{c}\text { Nonvisible } \\
\text { Minorities }\end{array}$ & $\begin{array}{c}\text { Visible } \\
\text { Minorities }\end{array}$ & Total & $\begin{array}{c}\text { Percent of Visible } \\
\text { Minorities }\end{array}$ \\
\hline Librarians & 183 & 11 & 194 & $5.7 \%$ \\
\hline Nonlibrarians & 184 & 14 & 198 & $7.1 \%$ \\
\hline Other Professionals & 34 & 2 & 36 & $5.6 \%$ \\
\hline Paraprofessionals & 125 & 11 & 136 & $8.1 \%$ \\
\hline Other Support Staff & 25 & 1 & 26 & $3.8 \%$ \\
\hline
\end{tabular}




\begin{tabular}{|l|c|c|c|c|}
\hline \multicolumn{5}{|c|}{ TABLE 6} \\
Percentage Distribution of Management Position by Visible Minority Status \\
\hline Management Position & $\begin{array}{c}\text { Nonvisible } \\
\text { Minorities }\end{array}$ & $\begin{array}{c}\text { Visible } \\
\text { Minorities }\end{array}$ & Total & $\begin{array}{c}\text { Percent of Visible } \\
\text { Minorities }\end{array}$ \\
\hline Nonmanagement & 242 & 18 & 260 & $6.9 \%$ \\
\hline Supervisors & 52 & 5 & 57 & $8.8 \%$ \\
\hline Middle Management & 45 & 1 & 46 & $2.2 \%$ \\
\hline Senior Administrator & 28 & 1 & 29 & $3.4 \%$ \\
\hline
\end{tabular}

\begin{tabular}{|l|c|c|c|c|}
\hline \multicolumn{5}{|c|}{ TABLE 7 } \\
Percentage Distribution of Educational Level by Visible Minority Status \\
\hline Highest Degree Obtained & $\begin{array}{c}\text { Nonvisible } \\
\text { Minorities }\end{array}$ & $\begin{array}{c}\text { Visible } \\
\text { Minorities }\end{array}$ & Total & $\begin{array}{c}\text { Percent of Visible } \\
\text { Minorities }\end{array}$ \\
\hline Without a graduate degree & 160 & 13 & 173 & $7.5 \%$ \\
\hline Master's degree & 200 & 12 & 212 & $5.7 \%$ \\
\hline PhD & 7 & 0 & 7 & 0 \\
\hline
\end{tabular}

Table 6 shows the percentage distribution of management position by visible minority status. The percentage of library practitioners who do not hold any management position and are visible minorities is 6.9 percent. Supervisors $(8.8 \%)$

\begin{tabular}{|l|l|c|}
\hline \multicolumn{3}{|c|}{ TABLE 8} \\
Mean Annual Salary by Visible Minority Status \\
\hline Status & Mean & Standard Deviation \\
\hline Visible minorities & $\$ 50,377.61$ & $20,637.55$ \\
\hline Nonvisible minorities & $\$ 68,239.56$ & $27,162.92$ \\
\hline
\end{tabular}
have the higher rate of visible minorities than middle management $(2.2 \%)$ and senior administrators (3.4\%). In terms of the highest degree obtained (see table 7), 5.7 percent of those who have a master's degree are visible minorities; no visible minorities have a PhD.

Table 8 illustrates the difference between visible minorities and nonvisible minorities in their mean annual salary. However, whether such a difference is significant should be examined, after controlling for all of the other variables described in table 4 . That will be the focus of the next section.

\section{Model Specifications}

Two sequential ordinary-least-squares (OLS) regression models are estimated with lnsalary as the dependent variable. The models are run first for all library practitioners in the sample.

lnsalary $=\mathrm{B}_{0}+\mathrm{B}_{1} *$ vismin $+\varepsilon(1)$

lnsalary $=\mathrm{B}_{0}{ }^{\prime}+\mathrm{B}_{1}{ }^{\prime} *$ vismin $+\mathrm{B}_{\mathrm{xj}} * \mathrm{X}_{\mathrm{j}}+\varepsilon(2)$

Model 1 includes only one dummy variable: visible minority (vismin). $B_{0}$ represents the intercept of the equation, $B_{1}$ is coefficient for visible minority, which represents the difference in Insalary between visible minorities and nonvisible minorities in the sample. Model 2 adds the covariates as described in table $4 . B_{x j}$ is a vector of coefficients for each of the covariates to salary, and $\varepsilon$ is a vector of random error terms. The change in the coefficient associated with vismin from Model 1 to Model $2\left(\mathrm{~B}_{1}-\mathrm{B}_{1}{ }^{\prime}\right)$ is the portion of the observed difference in lnsalary between visible minority and nonvisible minority library practitioners that is accounted for by the included covariates. 
The same sequential OLS regression models are also run separately for librarians and support staff, including paraprofessionals and other support staff. To make an easier comparison of the regression results between the two groups, all variables and categories use the same names as displayed in table 4, whereas the two variables without a graduate degree and master's degree are defined differently for librarians. As having an MLIS (or equivalent) degree is required to enter the librarian profession in Canada, it is more meaningful to examine if having an additional master's degree would have a significant impact on the librarian's salary. Hence, for librarians specifically, without a graduate degree means that the librarian does not have any additional master's degree or one has MLIS (or equivalent) only, and master's degree means having additional master's degree(s). Please note that the number of additional master's degrees one possesses is not taken into account in this study. Of the 194 librarians, 137 (71\%) have MLIS (or equivalent) only and 52 $(27 \%)$ have additional master's degree(s). For the support staff, these two variables are defined in the same way as they are in the models for the full sample: without a graduate degree means that one does not have any master's degree, and master's degree means having any master's degree.

\section{Results}

\section{All Library Practitioners}

OLS regression models are run first for all library practitioners, and the results are presented in table 9 (columns 2 and 3). Model 1 simply estimates the observed differences in lnsalary by visible minority status without accounting for other variables. Visible minorities have an average log salary gap of 0.408 relative to nonvisible minorities, which is statistically significant at $p<0.01$. In Model 2, with selected controlled variables added, visible minority remains highly statistically significant to lnsalary $(p<0.01)$. The coefficient for visible minority decreases from -0.408 in Model 1 to -0.256 in Model 2, suggesting that 37 percent of the observed average log salary gap between visible minorities and nonvisible minorities can be explained by their differences in the controlled variables.

\begin{tabular}{|l|c|c|c|c|c|c|}
\hline \multicolumn{7}{|c|}{ TABLE 9 } \\
\multicolumn{7}{|c|}{ Regression Results for Insalary } \\
\hline & \multicolumn{2}{|c|}{ All Practitioners } & \multicolumn{2}{c|}{ Librarians } & \multicolumn{2}{c|}{ Support Staff } \\
\cline { 2 - 7 } & Model 1 & Model 2 & Model 1 & Model 2 & Model 1 & Model 2 \\
\hline Visible minority & $-0.408^{\ddagger}$ & $-0.256^{\ddagger}$ & $-0.407^{\ddagger}$ & $-0.173^{\dagger}$ & $-0.322^{\dagger}$ & $-0.303^{\dagger}$ \\
& $(0.101)$ & $(0.065)$ & $(0.115)$ & $(0.080)$ & $(0.147)$ & $(0.124)$ \\
\hline Age & & $0.039^{\ddagger}$ & & $0.039^{\dagger}$ & & $0.048^{\dagger}$ \\
& & $(0.012)$ & & $(0.016)$ & & $(0.020)$ \\
\hline Age-squared & & $-0.000^{\ddagger}$ & & $-0.000^{\dagger}$ & & $-0.000^{\dagger}$ \\
& & $(0.000)$ & & $(0.000)$ & & $(0.000)$ \\
\hline Female & & -0.020 & & 0.012 & & -0.008 \\
& & $(0.040)$ & & $(0.045)$ & & $(0.077)$ \\
\hline Disabled & & 0.039 & & 0.093 & & -0.085 \\
& & $(0.069)$ & & $(0.100)$ & & $(0.106)$ \\
\hline Experience in current library & & $0.006^{\ddagger}$ & & $0.010^{\ddagger}$ & & 0.004 \\
& & $(0.002)$ & & $(0.003)$ & & $(0.003)$ \\
\hline Master's degree & & $0.152^{*}$ & & 0.034 & & 0.060 \\
& & $(0.077)$ & & $(0.044)$ & & $(0.124)$ \\
\hline
\end{tabular}




\begin{tabular}{|c|c|c|c|c|c|c|}
\hline \multicolumn{7}{|c|}{$\begin{array}{c}\text { TABLE } 9 \\
\text { Regression Results for Insalary }\end{array}$} \\
\hline & \multicolumn{2}{|c|}{ All Practitioners } & \multicolumn{2}{|c|}{ Librarians } & \multicolumn{2}{|c|}{ Support Staff } \\
\hline & Model 1 & Model 2 & Model 1 & Model 2 & Model 1 & Model 2 \\
\hline $\mathrm{PhD}$ & & $\begin{array}{c}0.066 \\
(0.138)\end{array}$ & & $\begin{array}{l}-0.001 \\
(0.125)\end{array}$ & & \\
\hline \multicolumn{7}{|l|}{ Staff type (librarians) } \\
\hline Other professionals & & $\begin{array}{l}-0.042 \\
(0.074)\end{array}$ & & & & \\
\hline Paraprofessionals & & $\begin{array}{c}-0.267^{\ddagger} \\
(0.081)\end{array}$ & & & & \\
\hline Other support staff & & $\begin{array}{l}-0.323^{\ddagger} \\
(0.103) \\
\end{array}$ & & & & \\
\hline \multicolumn{7}{|l|}{ Position (nonmanagement) } \\
\hline Supervisors & & $\begin{array}{c}0.055 \\
(0.047)\end{array}$ & & $\begin{array}{c}0.043 \\
(0.059)\end{array}$ & & $\begin{array}{l}0.144^{*} \\
(0.078)\end{array}$ \\
\hline Middle management & & $\begin{array}{c}0.068 \\
(0.061)\end{array}$ & & $\begin{array}{c}0.058 \\
(0.061)\end{array}$ & & $\begin{array}{l}-0.070 \\
(0.279)\end{array}$ \\
\hline Senior administrators & & $\begin{array}{l}0.227^{\ddagger} \\
(0.082)\end{array}$ & & $\begin{array}{l}0.226^{\ddagger} \\
(0.082)\end{array}$ & & $\begin{array}{c}0.333 \\
(0.377) \\
\end{array}$ \\
\hline \multicolumn{7}{|c|}{ Job category (public services) } \\
\hline Technical services & & $\begin{array}{c}0.038 \\
(0.045) \\
\end{array}$ & & $\begin{array}{l}-0.050 \\
(0.056) \\
\end{array}$ & & $\begin{array}{c}0.033 \\
(0.073) \\
\end{array}$ \\
\hline Collections & & $\begin{array}{c}0.022 \\
(0.062) \\
\end{array}$ & & $\begin{array}{c}0.003 \\
(0.078) \\
\end{array}$ & & $\begin{array}{l}-0.010 \\
(0.104) \\
\end{array}$ \\
\hline Information technology & & $\begin{array}{l}0.146^{*} \\
(0.076)\end{array}$ & & $\begin{array}{c}0.139 \\
(0.094) \\
\end{array}$ & & $\begin{array}{c}0.117 \\
(0.153) \\
\end{array}$ \\
\hline Management & & $\begin{array}{c}0.003 \\
(0.075) \\
\end{array}$ & & $\begin{array}{l}-0.007 \\
(0.082) \\
\end{array}$ & & $\begin{array}{c}0.114 \\
(0.275) \\
\end{array}$ \\
\hline Other & & $\begin{array}{c}0.017 \\
(0.054) \\
\end{array}$ & & $\begin{array}{c}0.062 \\
(0.072) \\
\end{array}$ & & $\begin{array}{l}-0.056 \\
(0.087) \\
\end{array}$ \\
\hline Hours & & $\begin{array}{l}0.027^{\ddagger} \\
(0.003) \\
\end{array}$ & & $\begin{array}{l}0.022^{\ddagger} \\
(0.003)\end{array}$ & & $\begin{array}{l}0.060^{\ddagger} \\
(0.007)\end{array}$ \\
\hline Permanent & & $\begin{array}{l}0.230^{\ddagger} \\
(0.057) \\
\end{array}$ & & $\begin{array}{c}0.250^{\ddagger} \\
(0.059)\end{array}$ & & $\begin{array}{c}0.158 \\
(0.113) \\
\end{array}$ \\
\hline \multicolumn{7}{|l|}{ Province (Ontario) } \\
\hline British Columbia & & $\begin{array}{l}-0.061 \\
(0.064) \\
\end{array}$ & & $\begin{array}{l}-0.056 \\
(0.065) \\
\end{array}$ & & $\begin{array}{l}-0.100 \\
(0.145) \\
\end{array}$ \\
\hline Alberta & & $\begin{array}{l}0.100^{*} \\
(0.052) \\
\end{array}$ & & $\begin{array}{c}0.050 \\
(0.060) \\
\end{array}$ & & $\begin{array}{c}0.095 \\
(0.093) \\
\end{array}$ \\
\hline Saskatchewan & & $\begin{array}{c}-0.189^{\ddagger} \\
(0.059) \\
\end{array}$ & & $\begin{array}{c}0.081 \\
(0.088) \\
\end{array}$ & & $\begin{array}{l}-0.455^{\ddagger} \\
(0.094) \\
\end{array}$ \\
\hline Manitoba & & $\begin{array}{c}-0.199^{\dagger} \\
(0.083)\end{array}$ & & $\begin{array}{l}-0.059 \\
(0.101) \\
\end{array}$ & & $\begin{array}{c}-0.264^{*} \\
(0.154) \\
\end{array}$ \\
\hline
\end{tabular}




\begin{tabular}{|c|c|c|c|c|c|c|}
\hline \multicolumn{7}{|c|}{$\begin{array}{c}\text { TABLE } 9 \\
\text { Regression Results for Insalary }\end{array}$} \\
\hline & \multicolumn{2}{|c|}{ All Practitioners } & \multicolumn{2}{|c|}{ Librarians } & \multicolumn{2}{|c|}{ Support Staff } \\
\hline & Model 1 & Model 2 & Model 1 & Model 2 & Model 1 & Model 2 \\
\hline Quebec & & $\begin{array}{l}-0.054 \\
(0.042)\end{array}$ & & $\begin{array}{l}-0.049 \\
(0.047)\end{array}$ & & $\begin{array}{l}-0.059 \\
(0.078)\end{array}$ \\
\hline Nova Scotia & & $\begin{array}{l}-0.059 \\
(0.105) \\
\end{array}$ & & $\begin{array}{c}0.102 \\
(0.163) \\
\end{array}$ & & $\begin{array}{l}-0.192 \\
(0.147)\end{array}$ \\
\hline Constant & $\begin{array}{l}11.044^{\ddagger} \\
(0.025)\end{array}$ & $\begin{array}{l}8.827^{\ddagger} \\
(0.311)\end{array}$ & $\begin{array}{l}11.272^{\ddagger} \\
(0.027)\end{array}$ & $\begin{array}{l}9.100^{\ddagger} \\
(0.375)\end{array}$ & $\begin{array}{l}10.728^{\ddagger} \\
(0.040)\end{array}$ & $\begin{array}{l}7.372^{\ddagger} \\
(0.525)\end{array}$ \\
\hline Observations & 392 & 392 & 194 & 194 & 162 & 162 \\
\hline R-squared & 0.040 & 0.648 & 0.061 & 0.645 & 0.029 & 0.586 \\
\hline \multicolumn{7}{|c|}{ Standard errors in parentheses } \\
\hline${ }^{*} p<0.1,{ }^{+} p<0.05,{ }^{\ddagger} p<0.01$ & & & & & & \\
\hline
\end{tabular}

To gain a better understanding of the contribution of each controlled variable to the accounted portion of the negative effect of visible minority status, the researcher has performed both regression decomposition and Oaxaca decomposition using the coefficients from the pooled sample in the calculation. These two decomposition techniques produce the same results, as supported by Hou's study. ${ }^{43}$ In regression decomposition, the contribution of each covariate $X_{\mathrm{j}}$ to the overall "explained" effect is defined as follows:

$\beta_{\mathrm{xj}} * \rho_{\mathrm{xj}} / \sum\left(\beta_{\mathrm{xj}} * \rho_{\mathrm{xj}}\right)$

where $\beta_{\mathrm{xj}}$ is the standardized regression coefficients in Model 2 for all library practitioners, and $\rho_{\mathrm{xj}}$ is the bivariate correlation between visible minority and each covariate. As shown in table 10, the decomposition results reveal that racial differences in job characteristics play the largest role, explaining 62.9 percent of the explained racial salary gap. Racial differences in labor market characteristics (19.9\%) and individual characteristics (17.2\%) play smaller roles. Regarding the job characteristics, weekly hours is the predominant contributor $(42.3 \%)$ to the explained salary gap between visible minorities and nonvisible minorities. The contribution of staff type $(11.1 \%)$ to the racial salary gap is larger than that of management position ( $7 \%$ ) and that of job category (5.2\%). Within staff type, racial difference in paraprofessionals $(17.4 \%)$ is the largest contributor to the explained salary gap. Within management position, racial difference in senior administrators $(5.4 \%)$ explains the largest portion of the accounted effect of visible minority status on salary. In terms of job category, racial difference in information technology (IT) plays the largest role, explaining 5.8 percent of the explained salary gap.

In addition to visible minority status, the estimation of Model 2 in table 9 for all library practitioners yields a few other statistically significant variables. The three individual variables that are significant are age, age-squared, and experience in the current library. The coefficient of the age variable $(0.039)$ is positive and significant $(p<0.01)$, whereas the coefficient of agesquared $(-0.00037)$ is negative and significant $(p<0.01)$, suggesting that the impact of age on salary is not linear. In other words, salary increases with age as library practitioners become more experienced; but, as they get older, salary increases at a decreasing rate. Both the age and age-squared variable need to be considered to assess the overall impact of age on salary. 


\begin{tabular}{|c|c|}
\hline \multicolumn{2}{|c|}{$\begin{array}{c}\text { TABLE } 10 \\
\text { Decomposition of the Effect of Visible } \\
\text { Minority Status on Insalary }\end{array}$} \\
\hline Observed effect & -0.408 \\
\hline Adjusted effect & -0.256 \\
\hline Effect explained & $\begin{array}{l}-0.152(37 \% \text { of the } \\
\text { observed effect) }\end{array}$ \\
\hline Contributing components & $\begin{array}{l}\% \text { of the effect } \\
\text { explained }\end{array}$ \\
\hline Individual Characteristics & $17.2 \%$ \\
\hline Female & $-0.8 \%$ \\
\hline Age & $17.4 \%$ \\
\hline Age squared & $-14.5 \%$ \\
\hline Disabled & $0.4 \%$ \\
\hline Experience in current library & $7.4 \%$ \\
\hline Master's degree & $6.5 \%$ \\
\hline $\mathrm{PhD}$ & $0.8 \%$ \\
\hline Job Characteristics & $62.9 \%$ \\
\hline Staff type & $11.1 \%$ \\
\hline Other professionals & $-0.3 \%$ \\
\hline Paraprofessionals & $17.4 \%$ \\
\hline Other support staff & $-6.0 \%$ \\
\hline Management position & $7.0 \%$ \\
\hline Supervisors & $-2.1 \%$ \\
\hline Middle management & $3.7 \%$ \\
\hline Senior administrators & $5.4 \%$ \\
\hline Job category & $5.2 \%$ \\
\hline Technical services & $-1.7 \%$ \\
\hline Collections & $1.2 \%$ \\
\hline Information technology (IT) & $5.8 \%$ \\
\hline Management & $0.2 \%$ \\
\hline Other category & $-0.2 \%$ \\
\hline Permanent & $-2.7 \%$ \\
\hline Hours & $42.3 \%$ \\
\hline Labor Market Characteristics & $19.9 \%$ \\
\hline British Columbia & $5.2 \%$ \\
\hline Alberta & $3.9 \%$ \\
\hline Saskatchewan & $13.3 \%$ \\
\hline Manitoba & $-5.7 \%$ \\
\hline Quebec & $2.6 \%$ \\
\hline Nova Scotia & $0.6 \%$ \\
\hline Total & $100 \%$ \\
\hline
\end{tabular}

The percentage impact of age on salary for the library practitioners is calculated using the equation below:

Coefficient of age $+2 *$ (coefficient of agesquared) $*$ Mean of age

At the average age of 45.6 years, this gives: $0.039+2 *(-0.00037) *(45.6)=0.005$, or a return of about 0.5 percent per year of age on average. In other words, with a oneyear increase in age, salary increase by 0.5 percent, all else being equal. This result is consistent with Sweeper and Smith's study of the library science labor market in the United States. ${ }^{44}$ In addition, experience in the current library is significant at the 0.01 level, with an additional year of experience leading to 0.6 percent increase in salary.

Of the job variables that are significant in Model 2, hours and permanent are both significant at 0.01 level and can be interpreted as follows: per additional hour per week increases salary by 2.7 percent, and having a permanent job translates into an increase of 23 percent in salary, compared to a temporary job, while holding other factors constant. Regarding the staff type, the coefficients of paraprofessionals and other support staff are both negative and significant at the 0.01 level, with a 26.7 percent and 32.3 percent salary gap respectively, compared with librarians. In terms of management positions, this research does not support Sweeper and Smith's findings that being supervisors significantly increases earnings; ${ }^{45}$ instead, it shows that being senior administrators significantly increases salary by 22.7 percent $(p<0.01)$. In addition, the library staff living in Saskatchewan and Manitoba earn 18.9 percent $(p<0.01)$ and 19.9 percent $(p<0.05)$ respectively less than their counterparts in Ontario.

\section{Librarians versus Support Staff}

The same OLS regression models are separately estimated using samples of librarians 
and support staff, and the results are presented in table 9 (columns 4-7). The negative coefficient for visible minority is statistically significant for both librarians $(p<0.01)$ and support staff $(p<0.05)$. Among librarians, the average salary of visible minorities is 40.7 percent less compared to nonvisible minorities $(p<0.01)$. The corresponding gap is 32.2 percent for support staff $(p<0.05)$. From Model 1 to Model 2 for the librarians, the coefficient for visible minority drops from -0.407 to -0.173 , suggesting that 57 percent of the observed racial differences in Insalary can be explained by their differences in the controlled variables. In comparison, from Model 1 to Model 2 for the support staff, the coefficient for visible minority decreases from -0.322 to -0.303 , suggesting that the differences in the controlled variables can explain only 6 percent of the observed salary gap between visible minorities and nonvisible minorities. As such, on average, the negative effect of visible minority status on salary is stronger for support staff than for librarians.

In addition to visible minority status, a few other variables are statistically significant for librarians, including age, age-squared, experience in the current library, senior administrators, hours, and permanent job. Using the same technique for calculating the combined impact of age and age-squared as stated earlier, the analysis shows that at the average age of 45.1 years, with a one-year increase in age, librarians' salary increases by a 0.5 percent on average, all else being equal. An additional year of experience in the current library translates into a 1 percent increase in librarians' salary on average, which is consistent with Siebert and Young's study. ${ }^{46}$ Senior administrators earn 22.6 percent more than nonmanagement, and per additional weekly hour increases salary by 2.2 percent. Moreover, having a permanent job translates into an increase of 25 percent in salary.

In contrast, far fewer variables are statistically significant for support staff. Age and age-squared remain significant. As is the case for librarians, at the average age of 45.8 years, a one-year increase in age increases salary by 0.5 percent, all else being equal. An additional weekly hour significantly increases salary by 6 percent, higher than its effect for librarians $(2.2 \%)$. Support staff in Saskatchewan on average earn 45.5 percent $(p<0.01)$ less than their counterparts in Ontario, holding other things constant. Other variables that are significant for librarians lose significance for support staff, including experience in the current library, permanent job, and senior administrators.

\section{Discussion}

The research findings show that there is a significant salary gap between visible minorities and nonvisible minorities in CARL libraries. This result is disappointing, considering that some recent studies have found the racial pay gap closed in the library science labor market in the United States. ${ }^{47}$ However, it is not surprising given the fact that pay equity challenges have persisted for decades in Canada. This research provides evidence that the experiences of visible minorities in CARL libraries do not differ from those of workers in the general labor market. As visible minorities are underrepresented in CARL libraries, practicing toward racial pay equity is important to recruit and retain visible minorities in the workplace and address the diversity gap. Both universities and CARL have realized the importance of employment equity. Employment equity policies or plans have been in place in large universities; however, they are usually very broad, just providing guidance on general equity principles. ${ }^{48}$ Increasing hires for visible minorities is often clearly stated as a numerical employment equity goal, such as Memorial University's Employment Equity and Diversity Plan: 2019-2021. ${ }^{49}$ Yet pay equity is 
not explicitly specified as a measurable indicator of successful implementation of employment equity in institutional policies. It is commendable that CARL has prioritized equity, diversity, and inclusion (EDI) as an important area for capacity building within its members. In May 2019, CARL announced a newly created role of Visiting Program Officer for EDI, who, with the support of an advisory working group composed of librarians across Canada, would guide the development of CARL's EDI initiatives. ${ }^{50}$ There is not a clear statement as to what the future diversity efforts in CARL libraries would entail. The findings from this research suggest that more attention needs to be given to the racial pay equity and a comprehensive assessment is necessary in CARL libraries. As the negative effect of visible minority status on salary is shown to be stronger for support staff than for librarians, more efforts need to be put into reducing racial pay gap among support staff, although that is an important issue to tackle for librarians as well.

The decomposition results indicate that 37 percent of the salary gap between visible minority and nonvisible minority library practitioners can be explained by their differences in the controlled variables. Yet a large portion of the gap, 63 percent, remains unexplained. A review of research on gender earnings differences finds that no method exists for measuring discrimination directly, and the unexplained sex-linked residual is usually used to estimate the effect of sex discrimination. ${ }^{51}$ This provides a clue for us to understand the unexplained portion of the racial salary gap in this research. On one hand, it may reflect personal choices of the library practitioners in the aspects that are not included as explanatory variables in this analysis. On the other hand, it may reflect discrimination in hiring decisions by employers or more systemic discrimination affecting the labor market opportunities and job-related decisions of individuals. ${ }^{52}$ Visible minorities belong to one of the designated groups that tend to experience discrimination in the Canadian labor market. In the postsecondary education environment, CAUT has acknowledged that "systemic discrimination has manifested itself in barriers to access, employment, governance, inclusion, respect, and acceptance." ${ }^{53}$ Federal Contractors Program (FCP) was established in 1986 to require universities as contractors under the FCP to commit to implementing employment equity because data show that disadvantage against four designated groups persists to this day including women, Aboriginal peoples, members of visible minorities, and persons with disabilities. ${ }^{54}$ Although it is not safe to assign all the unexplained portion of salary gap to discrimination against visible minorities, to what extent the salary gap might be caused by discrimination merits further research.

The research results also confirm the findings of Dowell ${ }^{55}$ and Van House ${ }^{56}$ that a higher level of position is significant to librarians' salaries. In particular, they illustrate the significant impact of being senior administrators on the earnings attainment process. In reality, it has been cited that "librarians with early success in frontline and middlemanagement roles are uncomfortable with the idea of moving toward senior levels of leadership." ${ }^{57}$ Overall, the senior administration of academic libraries in Canada does not reflect the population demographic it serves. Particularly, visible minority librarians are confronted with challenges in rising to senior leadership positions due to lack of access to network, lack of mentorship, lack of training and other reasons. ${ }^{58}$ The findings from this research may be encouraging to some librarians to move up their career from a financial incentive perspective. 


\section{Limitations and Further Research}

The results of this study are based on a sample of 392 individuals employed in CARL libraries only. This sample is not representative of all Canadian academic libraries and their staff. The study is also limited by preexisting variables in the 8Rs Practitioner Survey. For instance, province is the only available labor market variable in the survey. As stated in the Measures section, three provinces (Prince Edward Island, Newfoundland and Labrador, and New Brunswick) are not included in the analysis. All these limitations suggest that caution is needed in generalizing the results from this research to all academic libraries across Canada. However, it is important to note that empirical studies of the effect of race on earnings in library science are few. This study will form the basis for continued work in this area. Possibilities for future research include further examination of how the adjusted effect of visible minority status on salary would change over time. Since this research examines visible minorities in general, if more data were available, further research could permit a more detailed analysis of earnings differentials across racial/ethnic groups such as Asian, Black, and Hispanic. Additionally, it would be meaningful to conduct a comparative study of the racial salary gap between CARL libraries and non-CARL libraries or between academic libraries and public libraries. Another area for future research would be a more in-depth examination of the impacts of specific factors on the racial salary gap, such as hiring, promotion, and access to senior positions, particularly the discrimination against visible minorities in the library science labor market.

\section{Conclusion}

CARL libraries have made progress in hiring and retaining employees from underrepresented groups, although the number of ethnic minority employees is still fairly low compared to the Canadian labor force. There has been a lack of study on the racial pay gap in academic libraries. This research examines the impact of visible minority status on salaries of CARL library practitioners, controlling for individual, job, and labor market variables. Research findings reveal that visible minority status has a significant impact on salary, with the negative effect being stronger for support staff than for librarians. CARL libraries should continue to develop and improve initiatives to foster racial equity. Pay gap needs to be taken into account when assessing racial equity among each type of library staff. ARL libraries have made great strides in the last three decades toward decreasing the racial pay gap, and CARL libraries can learn from their best practices. Future research efforts should seek to provide practical recommendations for the evaluation of improvement initiatives in CARL libraries. Additionally, the decomposition analysis indicates that racial differences in job characteristics account for a larger portion of the explained racial salary gap than individual and labor market characteristics. Unexplained portion of the racial salary difference can be partially attributed to discrimination, which warrants further study. Future research would also include more in-depth examination of racial salary gap in other types of libraries, by ethnicity groups as well as its change over time.

\section{Notes}

1. Barbara Dewey and Jillian Keally, "Recruiting for Diversity: Strategies for Twenty-First Century Research Librarianship," Library Hi Tech 26, no. 4 (2008): 622-29; Mary Kandiuk, "Promoting Racial and Ethnic Diversity among Canadian Academic Librarians," College \& Research Libraries 75, no. 4 (2014): 492-556.

2. Canadian Association of University Teachers (CAUT), "Policy Statement on Equity," available online at https://www.caut.ca/about-us/caut-policy/lists/caut-policy-statements/policy-statement-on-equity [accessed 2 
November 2019].

3. Kandiuk, "Promoting Racial and Ethnic Diversity"; Maha Kumaran and Heather Cai, "Identifying the Visible Minority Librarians in Canada: A National Survey," Evidence Based Library and Information Practice 10, no. 2 (2015): 108-26; Deborah Lee and Maha Kumaran, Aboriginal and Visible Minority Librarians: Oral Histories from Canada (Lanham, MD: Scarecrow, 2014).

4. Kathleen Delong, Marianne Sorensen, and Vicki Williamson, "8Rs Redux CARL Libraries Human Resources Study" (May 2015), 3-4, available online at www.carl-abrc.ca/wp-content/uploads/docs/8Rs_REDUX_Final_Report_Oct2015.pdf [accessed 10 November 2019].

5. Government of Canada, "Employment Equity Act (S.C. 1995, c. 44)," available online at https://laws-lois. justice.gc.ca/eng/acts/e-5.401/ [accessed 16 November 2019].

6. United Nations, "International Convention on the Elimination of All Forms of Racial Discrimination: Concluding Observations on the Combined Twenty-First to Twenty-Third Periodic Reports of Canada," available online at https://www.hr-dp.org/files/2019/10/22/Concluding_observations_on_the_combined_twentyfirst_to_twenty-third_periodic_reports_of_Canada1.pdf [accessed 16 November 2019].

7. Kumaran and Cai, "Identifying the Visible Minority Librarians in Canada," 109.

8. Kandiuk, "Promoting Racial and Ethnic Diversity," 507.

9. Delong, Sorensen, and Williamson, "8Rs Redux CARL Libraries Human Resources Study," 15.

10. Statistics Canada, "Occupation-National Occupational Classification (NOC) 2016 (691), Employment Income Statistics (3), Highest Certificate, Diploma or Degree (7), Visible Minority (15), Work Activity During the Reference Year (4), Age (4D) and Sex (3) for the Population Aged 15 Years and Over Who Worked in 2015 and Reported Employment Income in 2015, in Private Households of Canada, Provinces and Territories and Census Metropolitan Areas, 2016 Census-25\% Sample Data," available online at https://www12.statcan.gc.ca/global/ URLRedirect.cfm?lang=E\&ips=98-400-X2016356 [accessed 1 December 2019].

11. Statistics Canada, "Visible Minority (15), Age (15A), Sex (3) and Selected Demographic, Cultural, Labour Force, Educational and Income Characteristics (900) for the Population in Private Households of Canada, Provinces and Territories, Census Metropolitan Areas and Census Agglomerations, 2016 Census-25\% Sample Data," available online at https://www150.statcan.gc.ca/n1/en/catalogue/98-400-X2016192 [accessed 1 December 2019].

12. Canadian Association of Professional Academic Librarians (CAPAL), "2016 Census of Canadian Academic Librarians User Guide and Results Summary," 37, available online at https://capalibrarians.org/wp/wp-content/ uploads/2016/12/Census_summary_and_user_guide_December_16_2016.pdf [accessed 1 December 2019].

13. Canadian Association of Professional Academic Librarians (CAPAL), "2018 Census of Canadian Academic Librarians User Guide and Results Summary," 66, available online at https://capalibrarians.org/wp/wp-content/ uploads/2019/03/2018_Census_March_24_2019.pdf [accessed 4 December 2019].

14. Delong, Sorensen, and Williamson, "8Rs Redux CARL Libraries Human Resources Study," 174.

15. Statistics Canada, "Occupation-Standard Occupational Classification 1991 (Historical) (707), Age Groups (12A) and Sex (3) for the Labour Force 15 Years and Over of Canada, Provinces, Territories, Census Metropolitan Areas and Census Agglomerations, 1996 to 2006 Censuses-20\% Sample Data," available online at https:// www12.statcan.gc.ca/global/URLRedirect.cfm?lang=E\&ips=97-559-XCB2006012 [accessed 4 December 2019].

16. Jack Hang-tat Leong, "Ethnic Diversity at the University of Toronto Libraries" (International Federation of Library Associations [IFLA] Conference, August 15-23, 2013, Singapore), 4, available online at http://library. ifla.org/67/1/101-leong-en.pdf [accessed 5 December 2019].

17. Statistics Canada, “Total Income Groups (22), Sex (3), Visible Minority Groups (14A) and Immigrant Status (3) for Population 15 Years and Over, for Canada, Provinces and Territories, 1995 and 2000-20\% Sample Data," available online at https://www12.statcan.gc.ca/global/URLRedirect.cfm?lang=E\&ips=97F0020XCB2001044 [accessed 5 December 2019].

18. Ibid.

19. Statistics Canada, “Income Statistics (4) in Constant (2005) Dollars, Age Groups (5A), Generation Status (4), Visible Minority Groups (15), Highest Certificate, Diploma or Degree (5) and Sex (3) for the Population 15 Years and Over With Income of Canada, Provinces, Territories, Census Metropolitan Areas and Census Agglomerations, 2000 and 2005-20\% Sample Data," available online at https://www12.statcan.gc.ca/global/URLRedirect. cfm?lang=E\&ips=97-563-XCB2006007 [accessed 5 December 2019].

20. Statistics Canada, "Visible Minority (15), Age Groups (10), Sex (3) and Selected Demographic, Cultural, Labour Force, Educational and Income Characteristics (315) for the Population in Private Households of Canada, Provinces, Territories, Census Metropolitan Areas and Census Agglomerations, 2011 National Household Survey," available online at https://www12.statcan.gc.ca/global/URLRedirect.cfm?lang=E\&ips=99-010-X2011038 [accessed 5 December 2019].

21. Statistics Canada, "Visible Minority (15), Income Statistics (17), Generation Status (4), Age (10) and Sex (3) 
for the Population Aged 15 Years and Over in Private Households of Canada, Provinces and Territories, Census Metropolitan Areas and Census Agglomerations, 2016 Census-25\% Sample Data," available online at https:// www12.statcan.gc.ca/global/URLRedirect.cfm?lang=E\&ips=98-400-X2016210 [accessed 5 December 2019].

22. Statistics Canada, “Occupation-National Occupational Classification (NOC) 2016 (691), Employment Income Statistics (3), Highest Certificate, Diploma or Degree (7), Visible Minority (15), Work Activity During the Reference Year (4), Age (4D) and Sex (3) for the Population Aged 15 Years and Over Who Worked in 2015 and Reported Employment Income in 2015, in Private Households of Canada, Provinces and Territories and Census Metropolitan Areas, 2016 Census-25\% Sample Data," available online at https://www12.statcan.gc.ca/global/ URLRedirect.cfm?lang=E\&ips=98-400-X2016356 [accessed 1 December 2019]."

23. Kandiuk, "Promoting Racial and Ethnic Diversity," 510.

24. Darren Sweeper and Steven A. Smith, "Assessing the Impact of Gender and Race on Earnings in the Library Science Labor Market," CollegeE Research Libraries 71, no. 2 (2010): 171-83.

25. Quinn Galbraith, Heather Kelley, and Michael Groesbeck, "Is There a Racial Wage Gap in Research Libraries? An Analysis of ARL Libraries," College E Research Libraries 79, no. 7 (2018): 863-75.

26. Quinn Galbraith, Erin Merrill, and Olivia Outzen, "The Effect of Gender and Minority Status on Salary in Private and Public ARL Libraries," Journal of Academic Librarianship 44, no. 1 (2018): 75-80.

27. Canadian Association of University Teachers (CAUT), "Almanac of Post-Secondary Education 2019- Academic Staff: Table 3.7," available online at https://www.caut.ca/resources/almanac/3-academic-staff [accessed 13 November 2019].

28. Robert K. Toutkoushian, Marcia L. Bellas, and John V. Moore, "The Interaction Effects of Gender, Race, and Marital Status on Faculty Salaries," Journal of Higher Education 78, no. 5 (2007): 595.

29. Toutkoushian, Bellas, and Moore, "The Interaction Effects of Gender, Race, and Marital Status on Faculty Salaries," 576.

30. Sweeper and Smith, "Assessing the Impact of Gender and Race on Earnings in the Library Science Labor Market," 173-74.

31. Nancy A. Van House, "Salary Determination and Occupational Segregation among Librarians," Library Quarterly: Information, Community, Policy 56, no. 2 (1986): 142-66.

32. W.S. Siebert and A. Young, "Sex and Family Status Differentials in Professional Earnings: The Case of Librarians," Scottish Journal of Political Economy 30, no. 1 (1983): 18-39.

33. Deborah Olean Lee, "Faculty Status, Tenure, and Compensating Wage Differentials among Members of the Association of Research Libraries" (PhD diss., Mississippi State University, 2005); Deborah O. Lee, Kevin E. Rogers, and Paul W. Grimes, "The Union Relative Wage Effect for Academic Librarians," Industrial Relations: A Journal of Economy and Society 45, no. 3 (2006): 478-84.

34. Jeffrey Pfeffer and Alison Davis-Blake, "Determinants of Salary Dispersion in Organizations," Industrial Relations: A Journal of Economy and Society 29, no. 1 (1990): 38-57; Michael R. Ransom, "Seniority and Monopsony in the Academic Labor Market," American Economic Review 83, no. 1 (1993): 221-33; Allen L. Webster, "Demographic Factors Affecting Faculty Salary," Educational and Psychological Measurement 55, no. 5 (1995): 728-35; Robert K. Toutkoushian, "Racial and Marital Status Differences in Faculty Pay," Journal of Higher Education 69, no. 5 (1998): 513-41.

35. Canadian Association of Research Libraries (CARL), "Statistics," available online at www.carl-abrc.ca/ measuring-impact/statistics/ [accessed 3 December 2019].

36. Canadian Association of University Teachers (CAUT), “CAUT Education Review: Librarians in Canada's Universities \& Colleges State of the Profession 2000-2014" (May 2017), available online at https://www.caut.ca/ sites/default/files/caut-education-review-2017-05_0.pdf [accessed 30 October 2019].

37. The 8Rs Research Team, The Future of Human Resources in Canadian Libraries (Edmonton: University of Alberta, 2005), available online at http://www.ls.ualberta.ca/8rs/8RsFutureofHRLibraries.pdf [accessed 30 October 2019].

38. Kathleen Delong, Marianne Sorensen, and Vicki Williamson, "8Rs Practitioner Survey Codebooks and Data," UAL Dataverse, V3, https://doi.org/10.7939/DVN/10459.

39. DeLong, Sorensen, and Williamson, "8Rs Redux CARL Libraries Human Resources Study," 9.

40. DeLong, Sorensen, and Williamson, "8Rs Redux CARL Libraries Human Resources Study," 9.

41. DeLong, Sorensen, and Williamson, "8Rs Practitioner Survey Codebooks and Data," 8.

42. DeLong, Sorensen, and Williamson, "8Rs Practitioner Survey Codebooks and Data," 8.

43. Feng Hou, "A General Approach to Effect Decomposition," Social Science Quarterly 95, no. 3 (2014): 902.

44. Sweeper and Smith, "Assessing the Impact of Gender and Race on Earnings in the Library Science Labor Market," 180.

45. Sweeper and Smith, "Assessing the Impact of Gender and Race on Earnings in the Library Science Labor 
Market," 179.

46. Siebert and Young, "Sex and Family Status Differentials in Professional Earnings," 31.

47. Galbraith, Kelley, and Groesbeck, "Is There a Racial Wage Gap in Research Libraries?" 872; Galbraith, Merrill, and Outzen, "The Effect of Gender and Minority Status on Salary in Private and Public ARL Libraries," 78; Sweeper and Smith, "Assessing the Impact of Gender and Race on Earnings in the Library Science Labor Market,"180.

48. Kandiuk, "Promoting Racial and Ethnic Diversity," 498.

49. Memorial University, "Employment Equity and Diversity Plan: 2019 to 2021," available online at https:// www.mun.ca/hr/services/Equity/EquityandDiversityPlanReport.pdf [accessed 31 May 2020].

50. Canadian Association of Research Libraries (CARL), "Announcing CARL's Visiting Program Officer and Working Group for Equity, Diversity, and Inclusion" (May 9, 2019), available online at www.carl-abrc.ca/news/ announcing-carls-visiting-program-officer-and-working-group-for-equity-diversity-and-inclusion/ [accessed 15 December 2019].

51. Van House, "Salary Determination and Occupational Segregation among Librarians," 144, 164.

52. Tammy Schirle, "The Gender Wage Gap in the Canadian Provinces, 1997-2014," Canadian Public Policy 41, no. 4 (2015): 314.

53. Canadian Association of University Teachers (CAUT), "Policy Statement on Equity," 2.

54. Government of Canada, "Employment Equity Data Report," 51, available online at https://www.canada. ca/en/employment-social-development/services/labour-standards/reports/employment-equity-data-report-2016. html\#h4.5 [accessed 10 December 2019].

55. David R. Dowell, "Sex and Salary in a Female Dominated Profession," Journal of Academic Librarianship 14, no. 2 (1988): 96.

56. Van House, "Salary Determination and Occupational Segregation among Librarians," 154.

57. Duane E. Webster and Deetta Jones Young, "Our Collective Wisdom: Succession Planning and the ARL Research Library Leadership Fellows Program," Journal of Library Administration 49, no. 8 (2009): 782.

58. Maha Kumaran, "Succession Planning Process that Includes Visible Minority Librarians," Library Management 36 , no. 6/7 (2015): 434-47. 